\title{
Effect of a Single or Double Soil Solarization to Control Verticillium Wilt in Established Olive Orchards in Spain
}

\author{
F. J. Lopez-Escudero and M. A. Blanco-Lopez, Departamento de Agronomía, ETSIAM, Universidad de Córdoba, \\ Apdo. 4240, 14080 Córdoba; Spain
}

\begin{abstract}
Lopez-Escudero, F. J., and Blanco-Lopez, M. A. 2001. Effect of a single or double soil solarization to control Verticillium wilt in established olive orchards in Spain. Plant Dis. 85:489-496.

Four soil solarization experiments were completed in three commercial olive orchards infested with Verticillium dahliae in southern Spain. Three of the experiments used lines of trees and one used individual plants. Plantations had different initial inoculum densities of the pathogen. Initial studies indicated that highly virulent (cotton-defoliating) isolates of the pathogen were present in Marinaleda (experiment I), which represents the first record of such isolates affecting olive trees in Europe. Solarization treatments were applied to lines of trees for either one (single) or two consecutive (double) years. Solarization significantly reduced pathogen populations in the top $20 \mathrm{~cm}$ of soil for at least 3 years in relation to control plots. Pathogen reduction after the single solarization obscured effects of the second solarization treatment. Decrease of inoculum density in soil by solarization did not correspond to a similar reduction in disease severity. Disease severity was reduced only in orchards with medium or high initial inoculum densities. A second soil solarization treatment did not improve the effect of single solarization on Verticillium wilt control. In orchards with low inoculum densities, soil solarization did not result in significant differences in disease incidence and severity, but improved recovery of trees from the disease. Soil-solarized plots remained free of weeds, but tress in solarized plots did not show significant growth increase measured by trunk perimeter.
\end{abstract}

Olive (Olea europaea L.) is the most important and traditional woody crop in Spain. In Andalucía (southern Spain), nearly $1,300,000$ ha of olive are planted, which represents about $64 \%$ of the total national olive area (3). Verticillium wilt of olive, caused by Verticillium dahliae Kleb., was first observed in Spain in 1975 (13). Since this time, the disease has spread with the increase in the olive hectarage $(11,41)$. The main contributing factor for the increase in disease incidence and severity has been the establishment of orchards in fields previously cropped with susceptible hosts of the pathogen $(1,8,15,45,50,61,62)$. Nevertheless, other means of transmission of the pathogen, such as the use of infected planting material or contaminated irrigation water $(17,44,49,51)$, cannot be dismissed as unimportant.

Losses to Verticillium wilt potentially are very severe due to the proximity of

Corresponding author: M. A. Blanco-Lopez

E-mail: mblanco@uco.es

Research was supported by grants no. AGF930740-CO2-02 and AGF97-0546 from the Comisión Interministerial de Ciencia y Tecnología (CICYT) and by partial financing of a bursary for the first author from the Consejo Superior de Investigaciones Científicas (CSIC), Spain.

Accepted for publication 16 January 2001.

Publication no. D-2001-0305-01R

(C) 2001 The American Phytopathological Society olive to highly virulent pathogenic cottondefoliating isolates of $V$. dahliae (7) that may infect this crop $(24,40,44)$. In Spain, defoliating isolates were restricted to the Marismas area of Andalucía in 1983 (10) where cotton is intensively grown. Later, they were detected in other cotton-growing areas in the Guadalquivir River valley (6) and now they represent a potential threat to new olive groves that are being planted close to this area (32).

Two characteristic syndromes of Verticillium wilt of olive have been described in southern Spain. These include apoplexy, which is a rapid and extensive dieback of twigs and branches of olive trees without loss of leaves; and a slow decline, characterized by a rapid drying out of inflorescences and progressive defoliation of twigs. Apoplexy occurs mainly in late winter and slow decline in the spring (8). Sometimes, sectorial symptoms occur and branches with dried-out inflorescences and healthy branches with olive fruit can be found on same tree. Affected trees may exhibit vascular discoloration irrespective of the syndrome type $(8,59,60)$.

Soil solarization is an effective technique in reducing inoculum density of soilborne pathogens such as V. dahliae and controls Verticillium wilt in herbaceous hosts $(9,28,34,38,46)$. Similarly, solarization has been used with several woody hosts affected by $V$. dahliae $(2,47,53)$ or other soilborne fungi $(33,48)$. The efficacy of solarization seems to be lower on woody than on herbaceous hosts due, in part, to residual inoculum that remains viable after solarization $(2,53)$ and to difficulties of tarping around woody plants.

Additionally, in spite of several studies of the short- or long-term effects of soil solarization $\quad(2,18,20,22,29,30,53,54,56)$, information related to consecutive applications of solarization is not available. Consequently, the objective of this study was to determine the effectiveness of single (one year) or double (two consecutive years) soil solarization treatments for control of Verticillium wilt in young olive orchards.

\section{MATERIALS AND METHODS}

Experimental plots and soil solarization treatments. Four field experiments (I to IV) were carried out during 1994 to 1997 in Andalucía at three plantations located in Marinaleda (experiment I), Zambra (experiments II and IV), and Lora (experiment III). Agronomic characteristics of the fields are given in Table 1. Experiments were formed by 12 (I and III) or 10 (II) tree lines with 6 (I), 10 (II), or 12 (III) trees per line. Experiments I to III consisted of solarization of tree lines; treatments were single or double solarization. Solarization was applied the first time during the summer of 1994 in experiments I and II, and in 1995 in experiment III. For each experiment, the first solarization was randomly applied to half of the tree lines forming the plot. The second solarization was applied the next year to half of the trees that were solarized the year before.

Experiment IV consisted of solarization of individual trees and was conducted in two zones selected on both sides of experiment II, based on previous observations of affected trees. For this experiment, solarization was applied once in 1995 to 34 trees. This experiment was carried out to compare the individual application of plastics with the treeline application on the reduction of $V$. dahliae and control of Verticillium wilt of olive. Independent of experiment, soil solarization was applied for a period of 5 to 8 weeks, starting in July and ending in mid-September when plastic tarps were removed.

Soil solarization. Experimental plot surfaces were mechanically cleared of weeds, debris, and large stones to avoid damaging plastic sheets. A shallow parallel trench was dug by hand or with a tractor $3 \mathrm{~m}$ from tree rows. Before solarization, plots were 
watered with an average dosage of 30 to 40 liters $/ \mathrm{m}^{2}$ using the irrigation system installed at the orchards (sprinkler irrigation for experiments I and II, drip irrigation for experiment III). In experiment IV, trees were furrow-irrigated at a rate of $500 \mathrm{li}$ ters/tree. In all cases, soil was moistened to a depth of at least $25 \mathrm{~cm}$. After 2 days, two transparent polyethylene sheets, $3 \mathrm{~m}$ wide and $50 \mu \mathrm{m}$ thick, were extended along both sides of the tree rows. The inner edges of the sheets were joined, stapled, and attached to the tree trunks. The outer edges of the tarps were buried in furrows to secure the plastic and to maintain temperature and moisture. In experiment IV, two 3by-6- $m$ plastic sheets were extended on two sides of each tree and were stapled and treated in the same manner as above. In order to reduce mixing of soil between mulched and control plots after the solarization period, soil was always tilled with a disc plough parallel to tree lines, and weeds were controlled by herbicides when necessary.

Soil temperature. Soil temperatures were registered twice daily with a simple needle thermometer at a depth of $15 \mathrm{~cm}$ during solarization periods. Recording times were between 0700 and 0800 and between 1330 and 1800, depending on the experiment. In experiment III during the second solarization in 1996, temperatures were continuously recorded by means of a data logger at depths of 15 and $30 \mathrm{~cm}$.

Inoculum density of $V$. dahliae in soil. In all experiments, populations of the pathogen were determined just before (July) and immediately after (September) solarization. One $200-\mathrm{g}$ soil sample was taken from the upper $20 \mathrm{~cm}$ along the tree row at $30 \mathrm{~cm}$ from the trunk of each tree with a cylindrical (3.5-by-22-cm) auger. For experiment IV, the subsamples were collected from each of 34 solarized trees and around a similar number of nonsolarized trees. Subsamples from each experimental plot were bulked, crumbled, and mixed. Soil samples were then air dried for 4 weeks at room conditions. Afterward, each composite sample was passed through a $0.8-\mathrm{mm}$ sieve to remove organic debris and bigger particles, mixed manually, and air dried for an additional 1 to 2 weeks. Inoculum density of $V$. dahliae was estimated by the wet-sieving technique of Huisman and Ashworth (26). Each sample $(25 \mathrm{~g})$ was suspended in $100 \mathrm{ml}$ of distilled water, shaken for $1 \mathrm{~h}$ at $270 \mathrm{rpm}$, and filtered through 35 - and $15-\mu \mathrm{m}$ sieves. The residue retained in the $35-\mu \mathrm{m}$ sieve was recovered in $100 \mathrm{ml}$ of distilled water. Finally, $1 \mathrm{ml}$ of the suspension was plated onto a modified sodium polypectate agar medium (12) with 10 replications. Plates were incubated at 22 to $24^{\circ} \mathrm{C}$ in the dark for 14 days, at which time soil residues were removed with tap water and colonies of $V$. dahliae were counted. Inoculum density in each soil sample was estimated by the number of colonies of $V$. dahliae and expressed as propagules or microsclerotia per gram of air-dried soil (ppg).

Disease progress and tree growth. Experiments I, II, and III were surveyed monthly for symptom development. Incidence and disease severity were estimated based on a 1-to-5 rating scale according to the percentage of affected plant tissue by any of the following symptoms: chlorosis, necrosis, or defoliation ( $1=$ no symptoms, $2=1$ to $33 \%, 3=34$ to $66 \% ; 4=67$ to 99\% symptomatic, and $5=$ dead plant). At the end of each experiment, the area under the disease progress curve (AUDPC) was estimated as the percentage with regard to the maximum possible value in the considered period, according to the formula based on Campbell and Madden (14): AUDPC = $\left[t / 2 \times\left(s_{2}+2 \times s_{3}+\ldots+2 \times s_{i-1}+s_{i}\right) / 5 \times\right.$ $n] 100$, where $t=$ interval in days between observations; $s_{i}=$ final mean severity; $5=$ maximum value of severity, and $n=$ number of observations).

Infection of the plants was confirmed by pathogen isolations from affected twigs during the observation period, and from all dead plants. For pathogen isolation, pieces of affected tissues were washed in running tap water, bark was removed, and woody tissues surface disinfested in $0.5 \%$ sodium hypochlorite for $1 \mathrm{~min}$. Chips of wood were placed onto potato-dextrose agar (PDA) or acidified PDA. Plates were incubated at $24^{\circ} \mathrm{C}$ in the dark for 5 to 6 days.
Isolates of $V$. dahliae from affected olive plants in the different experiments were used to characterize the morphology of their microsclerotia in water agar. The morphology of microsclerotia was studied in colonies grown on water agar (WA) in petri plates at $24^{\circ} \mathrm{C}$ for 21 days $(6,43)$. Moreover, isolates were characterized as defoliating or nondefoliating according to their pathogenicity on cotton cultivars and by use of random amplified polymorphic DNA (RAPD) and specific polymerase chain reaction (PCR) analyses using primers developed by Pérez-Artés et al. (35). The defoliating ability of isolates was evaluated by artificially inoculating cotton plants of cvs. Coker-310 and Acala SJ-5, susceptible and tolerant, respectively, to the disease (7).

Tree growth was estimated every 4 months by measuring the trunk circumference at $30 \mathrm{~cm}$ above ground level. For experiment IV, disease progress (incidence and severity of symptoms) was evaluated on individual solarized trees. Control trees were nonsolarized neighbor trees in experiment II.

\section{RESULTS}

Soil temperature. Soil solarization increased soil temperature in all experiments as compared with the nonsolarized controls. However, the degree of increase varied with year and experiment (Table 2). The difference in temperature between maximum values recorded in solarized plots and the corresponding values in nonsolarized plots, at the same recording time, ranged from 1.6 to $12.0^{\circ} \mathrm{C}$ (Table 2). The highest differences were registered in experiment II in 1994 (minimum $8.0^{\circ} \mathrm{C}$ and maximum $12.0^{\circ} \mathrm{C}$ ), with a maximum temperature reached in the solarized plots of $45.0^{\circ} \mathrm{C}$. In this field, where experiments II and IV were located, temperatures in 1995 were very similar. In experiment I, maximum temperatures in solarized plots were lower (36.3 and $39.0^{\circ} \mathrm{C}$ in 1994 and 1995 , respectively). Considerable temperature increases in solarized treatments were also achieved in experiment III, with maximum temperatures higher in $1995\left(43.5^{\circ} \mathrm{C}\right)$ than in 1996 $\left(40.7^{\circ} \mathrm{C}\right)$ at a depth of $15 \mathrm{~cm}$ (Table 2).

Table 1. Agronomic characteristics of experimental plots in olive orchards in Andalucía, southern Spain

\begin{tabular}{|c|c|c|c|}
\hline \multirow[b]{2}{*}{ Characteristics } & \multicolumn{3}{|c|}{ Experimental plot (location) } \\
\hline & I (Marinaleda) & II and IV (Zambra) & III (Lora) \\
\hline Date planted & 1993 & 1991 & 1987 \\
\hline Cultivar & Hojiblanca & Picual & Picual \\
\hline Tree spacing (m) & 8 by 8 & 7 by 7 & 7 by 7 \\
\hline Planting material & Private olive cuttings & Commercial olive cuttings & Commercial olive cuttings \\
\hline Previous crops & $\begin{array}{l}\text { Wheat-sunflower (rotation until 1989), } \\
\text { cotton (1990-92) }\end{array}$ & $\begin{array}{l}\text { Asparagus, garlic (until 1991); } \\
\text { potato (intercropped 1991-92) }\end{array}$ & Alfalfa 1985-87 \\
\hline Soil texture & Clay-loam & Clay & Sandy-loam \\
\hline Watering system & $\begin{array}{l}\text { Gravity irrigation } 5 \text { to } 6 \text { times/year, } \\
100 \text { to } 200 \text { liters per tree }\end{array}$ & Gravity/sprinkler irrigation & $\begin{array}{l}\text { Drip irrigation } 1 \text { time/week; } 15 \text { liters/tree } \\
\text { (February) to } 60 \text { liters/tree (June) }\end{array}$ \\
\hline Disease identified & February 1994 & April 1994 & October 1994 \\
\hline Disease incidence & $21 \%$ & $15 \%$ (variable) & 30 to $40 \%$ \\
\hline Border crops & Cotton, sunflower, wheat & Olive, vegetables & Pistachio, holm oak, cork oak, pasture \\
\hline
\end{tabular}


Disease symptoms and progress. Disease symptoms were similar in control and solarized plots but varied with experiment. In experiment I, first symptoms developed early in several periods (fall 1994, after first solarization, and spring 1995), with sudden apoplexy detected in young plants that replaced trees killed by Verticillium wilt. In experiments II and IV, disease incidence was low during the evaluation period and chlorosis was the most commonly observed symptom on diseased trees. Disease recovery was common in this plantation, and included production of new vascular tissues around old necrotic lesions in recovering trees, with new vegetative growth in the stems and branches that completely enveloped old necrotic parts of the xylem. Many diseased plants had suckers arising from the crown. Disease progress in experiment III was characterized by the presence of slow decline and apoplexy in the same tree. During October and November in 1995 and 1996, trees that had shown good growth the prior spring were affected by Verticillium wilt. Symptoms consisted of defoliation and fast apoplexies that affected trees completely or partially, and caused fruits to mummify and remain attached to necrotic twigs and branches.

In all experiments, $V$. dahliae was easily isolated from affected plants. Isolates of $V$. dahliae showed a mixture of elongated and rounded (experiment I) or only rounded (experiment II and III) microsclerotia on WA. Only isolates from experiment I were characterized as the defoliating pathotype according to RAPDPCR tests, whereas isolates from experiments II and III corresponded to the nondefoliating pathotype. Tests of pathogenicity on cotton cultivars confirmed the results obtained by PCR.

Effect of soil solarization on the inoculum density of $\boldsymbol{V}$. dahliae. Soil solarization reduced inoculum density of $V$. dahliae to nondetectable or very low levels, depending on the experiment and year (Table 3).
In experiment $\mathrm{I}$, the population of $\mathrm{V}$. dahliae in nonsolarized soil ranged from 14.1 (July 1995) to 28.6 ppg (September 1996) (Table 3). Inoculum density of the

pathogen also showed spatial variability in the experiment, even though the analysis of variance did not show a significant difference among nonsolarized

Table 3. Effect of soil solarization treatments on Verticillium dahliae in soils during 1994-96 in Andalucía, southern Spain ${ }^{y}$

\begin{tabular}{|c|c|c|c|c|c|c|}
\hline \multirow[b]{3}{*}{ Soil treatment } & \multicolumn{6}{|c|}{ Inoculum density (ppg) at record dates } \\
\hline & \multicolumn{2}{|c|}{1994} & \multicolumn{2}{|c|}{1995} & \multicolumn{2}{|c|}{1996} \\
\hline & July & Sept. & July & Sept. & July & Sept. \\
\hline \multicolumn{7}{|l|}{ Experiment I } \\
\hline Nonsolarized & 21.2 & $16.4 \mathrm{a}$ & $14.1 \mathrm{a}$ & $28.4 \mathrm{a}$ & $21.8 \mathrm{a}$ & $28.60 \mathrm{a}$ \\
\hline Once-solarized & 11.0 & $1.1 \mathrm{a}$ & $1.6 \mathrm{~b}$ & $9.6 \mathrm{~b}$ & $1.0 \mathrm{~b}$ & $2.60 \mathrm{~b}$ \\
\hline Twice-solarized & $\ldots$ & $\ldots$ & $1.6 \mathrm{~b}$ & $2.0 \mathrm{~b}$ & $0.6 \mathrm{~b}$ & $1.86 \mathrm{~b}$ \\
\hline \multicolumn{7}{|l|}{ Experiment II } \\
\hline Nonsolarized & 1.5 & $1.3 \mathrm{a}$ & $0.5 \mathrm{a}$ & $3.2 \mathrm{a}$ & $3.2 \mathrm{a}$ & $3.60 \mathrm{a}$ \\
\hline Once-solarized & 2.0 & $0.0 \mathrm{~b}$ & $0.0 \mathrm{a}$ & $0.8 \mathrm{a}$ & $0.7 \mathrm{~b}$ & $0.08 \mathrm{~b}$ \\
\hline Twice-solarized & $\ldots$ & $\ldots$ & $0.0 \mathrm{a}$ & $0.6 \mathrm{a}$ & $0.1 \mathrm{~b}$ & $0.16 \mathrm{~b}$ \\
\hline \multicolumn{7}{|l|}{ Experiment III } \\
\hline Nonsolarized & $\ldots$ & $\ldots$ & $0.0 \mathrm{a}$ & $13.3 \mathrm{a}$ & $4.9 \mathrm{a}$ & $0.6 \mathrm{a}$ \\
\hline Once-solarized & $\ldots$ & $\ldots$ & $0.0 \mathrm{a}$ & $0.0 \mathrm{~b}$ & $0.0 \mathrm{~b}$ & $0.2 \mathrm{a}$ \\
\hline Twice-solarized & $\ldots$ & $\ldots$ & $\ldots$ & $\ldots$ & $0.0 \mathrm{~b}$ & $0.0 \mathrm{a}$ \\
\hline
\end{tabular}

y Soil solarization was performed from July 17 to September 14 (experiment I), from July 19 to September 17 (experiment. II), and from July 28 to September 23 (experiment III) for once-solarized treatments. For twice-solarized treatments, solarization was applied from July 6 to September 13 (experiment. I), from July 21 to September 14 (experiment II), and from July 23 to September 28 (experiment III).

${ }^{\mathrm{z}}$ For each experiment and record date, values followed by the same letter are not significantly different at $P=0.05$ according to Fisher's protected least significant difference test; ppg = propagules per gram of air-dried soil; subsamples were taken from the upper $20 \mathrm{~cm}$ along the tree row at $30 \mathrm{~cm}$ from the trunk of each tree.

Table 4. Effect of soil solarization on the final values of estimated variables in the different experiments ${ }^{\mathrm{z}}$

\begin{tabular}{lccccc}
\hline Soil treatment & $\begin{array}{c}\text { Mean } \\
\text { severity }\end{array}$ & $\begin{array}{c}\text { Disease } \\
\text { incidence }(\boldsymbol{\%})\end{array}$ & $\begin{array}{c}\text { Plant death } \\
(\boldsymbol{\%})\end{array}$ & $\begin{array}{c}\text { Trunk } \\
\text { perimeter }(\mathbf{c m})\end{array}$ & $\begin{array}{c}\text { AUDPC } \\
(\boldsymbol{\%})\end{array}$ \\
\hline Experiment I & & & & & \\
$\quad$ Nonsolarized & $3.2 \mathrm{a}$ & $87.7 \mathrm{a}$ & 56.1 & 16.94 & $63.1 \mathrm{a}$ \\
Once-solarized & $1.8 \mathrm{~b}$ & $77.2 \mathrm{a}$ & 13.6 & 21.13 & $41.4 \mathrm{~b}$ \\
Twice-solarized & $3.2 \mathrm{a}$ & $84.8 \mathrm{a}$ & 30.3 & 18.84 & $52.8 \mathrm{ab}$ \\
Experiment II & & & & & \\
$\quad$ Nonsolarized & $1.3 \mathrm{a}$ & $34.0 \mathrm{a}$ & 10.2 & 24.53 & $26.5 \mathrm{a}$ \\
Once-solarized & $1.5 \mathrm{a}$ & $32.0 \mathrm{a}$ & 8.0 & 24.50 & $25.8 \mathrm{a}$ \\
Twice-solarized & $1.5 \mathrm{a}$ & $20.0 \mathrm{a}$ & 12.0 & 25.50 & $26.5 \mathrm{a}$ \\
Experiment III & & & & & \\
$\quad$ Nonsolarized & $3.5 \mathrm{a}$ & $93.0 \mathrm{a}$ & 5.3 & 18.84 & $47.3 \mathrm{a}$ \\
Once-solarized & $2.3 \mathrm{~b}$ & $75.0 \mathrm{ab}$ & 7.1 & 19.82 & $34.8 \mathrm{~b}$ \\
Twice-solarized & $2.2 \mathrm{~b}$ & $57.1 \mathrm{~b}$ & 7.1 & 21.48 & $36.2 \mathrm{ab}$ \\
\hline
\end{tabular}

${ }^{\mathrm{z}}$ For each experiment and variable, values followed by the same or no letter are not significantly different at $P=0.05$ according to Fisher's protected least significant difference test. AUDPC $=$ area under the disease progress curve.

Table 2. Effect of soil solarization treatments on soil temperature in the different experiments

\begin{tabular}{|c|c|c|c|c|c|c|c|}
\hline \multirow[b]{2}{*}{ Year, experiment } & \multirow[b]{2}{*}{ Depth $(\mathbf{c m})$} & \multicolumn{2}{|c|}{ Temperature recording ${ }^{x}$} & \multicolumn{2}{|c|}{ Maximum temperature $^{y}$} & \multicolumn{2}{|c|}{ Difference of temperatures ${ }^{\mathrm{z}}$} \\
\hline & & Period & Time & Solarized & Nonsolarized & Minimum & Maximum \\
\hline \multicolumn{8}{|l|}{1994} \\
\hline I & 15 & $28 \mathrm{Jul}-19$ Aug & 0730 and 1500 & 36.3 & 29.9 & 4.5 & 7.9 \\
\hline II & 15 & 27 Jul-9 Sep & 0800 and 1800 & 45.0 & 33.9 & 8.0 & 12.0 \\
\hline \multicolumn{8}{|l|}{1995} \\
\hline I & 15 & 2-19 Aug & 0700 and 1330 & 39.0 & 32.8 & 5.0 & 8.0 \\
\hline II & 15 & 3-17 Aug & 0800 and 1800 & 42.7 & 33.3 & 8.5 & 10.3 \\
\hline III & 15 & 3 Aug-16 Sep & 0700 and 1700 & 43.5 & 34.9 & 5.1 & 9.0 \\
\hline IV & 15 & 3-17 Aug & 0800 and 1800 & 42.7 & 33.1 & 8.9 & 10.1 \\
\hline \multicolumn{8}{|l|}{1996} \\
\hline \multirow[t]{2}{*}{ III } & 15 & 19 Jul-9 Sep & Continuously & 40.7 & 33.7 & 2.3 & 9.2 \\
\hline & 30 & 19 Jul-9 Sep & Continuously & 35.6 & 31.6 & 1.6 & 6.3 \\
\hline
\end{tabular}

${ }^{\mathrm{x}}$ Temperatures $\left({ }^{\circ} \mathrm{C}\right)$ were registered at a depth of $15 \mathrm{~cm}$ twice daily during different periods. In experiment III, in 1996, temperatures were continuously recorded at depths of 15 and $30 \mathrm{~cm}$ by means of a data logger.

y Temperatures $\left({ }^{\circ} \mathrm{C}\right)$ are maximum values recorded in solarized plots and the corresponding values in nonsolarized plots at the same recording time.

${ }^{\mathrm{z}}$ Values are differences $\left({ }^{\circ} \mathrm{C}\right)$ between temperatures in solarized plots and the corresponding values in nonsolarized plots at the same recording time. 
plots. The first solarization treatment reduced the inoculum density to low levels (1.1 ppg, September 1994). The inoculum density remained low during the subsequent 2 years in once-solarized plots at values significantly lower than the nonsolarized plots, except in September 1995, when it increased to 9.6
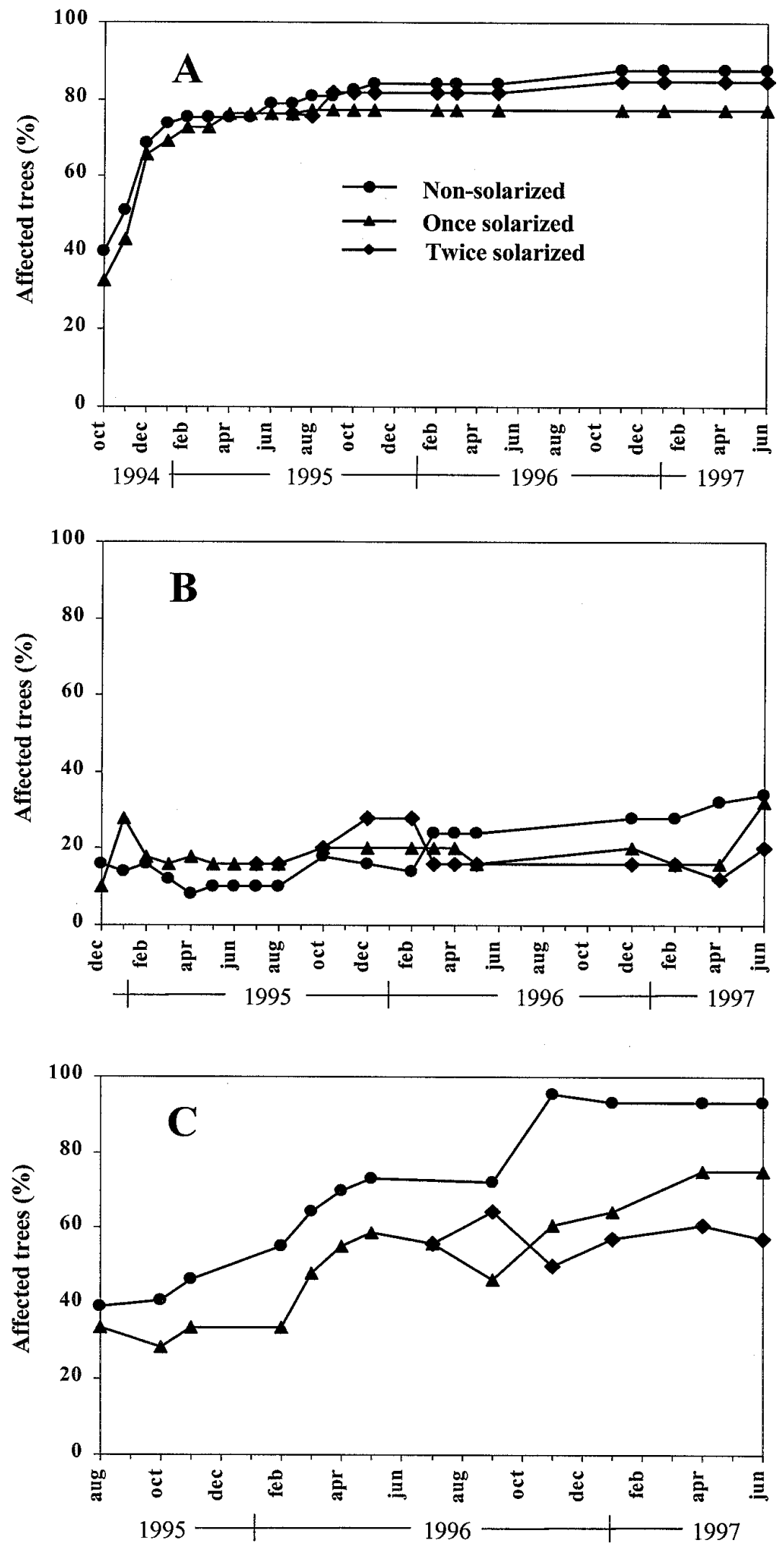

Fig. 1. Effect of soil solarization on the incidence of trees affected by Verticillium wilt in A, experiment I, B, experiment II, and $\mathbf{C}$, experiment III.

ppg. This increase did not occur in twicesolarized plots (Table 3 ).

In experiment II, population dynamics followed a trend similar to that in experiment I, but solarization was more effective in reducing the pathogen population to nondetectable levels after the first solarization (Table 3). In this experiment, inoculum density increases were suppressed by solarization until the end of the experiment (Table 3). However, residual inoculum in soil of both solarization treatments was found $(0.08$ and $0.16 \mathrm{ppg}$ with single and double solarization, respectively, in September 1996).

In experiment III, the pathogen was not detected in soil before solarization. However, the incidence of plants affected by wilt in this orchard was high. Nevertheless, after the first solarization, inoculum density in nonsolarized plots reached a very high value of $13.3 \mathrm{ppg}$ (Table 3 ). No significant differences were observed between single and double solarization and, in both cases, the pathogen population was reduced after the first solarization to nondetectable levels, and remained at this level for at least 2 years (Table 3).

In experiment IV, individual solarization in 1995 reduced pathogen populations from 4.2 (July) to $0.3 \mathrm{ppg}$ (September); values of inoculum density for nonsolarized plots in July and September were 3.2 to $5.2 \mathrm{ppg}$, respectively. One year after solarization, in summer 1996, soil analyses in solarized treatments showed that inoculum density remained low in July $(0.5 \mathrm{ppg})$ and September $(0.7 \mathrm{ppg})$. This summer, in nonsolarized plots, a slight reduction was detected in the population of the pathogen compared to 1995 values, although it was higher than in solarized treatments, with values of $2 \mathrm{ppg}$ (July) and $2.6 \mathrm{ppg}$ (September).

Effect of soil solarization on disease progress. The effect of soil solarization on disease progress varied with the experiment. In general, a decrease in inoculum density of $V$. dahliae did not correspond to a similar reduction in disease. Disease incidence was slightly (not statistically) reduced in experiment $\mathrm{I}$, with single solarization compared to the nonsolarized controls (Table 4, Fig. 1A). In experiment II, solarization did not result in significant differences in disease incidence and severity (Table 4, Figs. 1B and 2B). However, in experiment III, a significant disease reduction was observed after solarization (Table 4, Figs. $1 \mathrm{C}$ and 2C). The single solarization treatment significantly reduced the mean severity of infections, expressed as AUDPC, in experiments I and III, compared with the nonsolarized treatment (Table 4).

Disease progress in experiment I showed that only 1 year after the first solarization, Verticillium wilt of olive affected approximately $80 \%$ of the trees irrespective of treatment (Fig. 1A). Nevertheless, dis- 
ease severity diminished in once-solarized plots (Fig. 2A). In experiment II, disease incidence and symptom severity remained at low levels during the trial period and no statistical differences were observed (Table 4, Fig. 2B). In experiment III, disease incidence in the nonsolarized plots increased from an initial level of 40 to $93.0 \%$. In solarized treatments, incidence also increased, but after May 1996 remained constant (Fig. 1C). Final values of the disease severity were reduced by both single or double solarization (Table 4, Fig 2C).

In experiment IV, initial incidence in solarized trees was $56.2 \%$ and increased to 75\% in October 1995 and May 1996 (Fig. 3 ). Nevertheless, after this time, a continuous recovery from the disease was detected until the spring 1997 , when $41.7 \%$ of the trees exhibited symptoms of wilt. Disease severity remained constant during the experiment (Fig. 3).

Effect of soil solarization on tree growth and weed control. Measurement of the trunk circumference revealed no differences in any experiment with regard to solarization treatments. Nevertheless, in experiment III, trunk diameters for trees in plots solarized for two consecutive years were $14.0 \%$ larger in perimeter than in trees from the nonsolarized control plots (Table 4).

Soil solarization was very effective in controlling weeds, especially in experiment I, where the soil remained free of weeds for at least two seasons (after the first solarization). In experiment II, Portulaca oleracea and Juncia olivaris grew in localized groups under the plastic sheets in shady areas, especially on the north side of trees.

\section{DISCUSSION}

Verticillium wilt symptoms in experimental plots were similar to those previously described $(8,15,42,59,60)$, with the onset of symptoms depending on experiment. In experiment I, first symptoms were observed during the winter of 1994 , only a few months after the establishment of the plantation. The early expression of symptoms could be due to the use of infected planting material, high initial inoculum density, and presence of the defoliating isolate of the pathogen, or the use of the susceptible cultivar Hojiblanca (32). However, in the other orchards planted in the winter of 1991 (experiments II and IV) and October 1987 (experiment III), symptoms of the disease were not observed until 3 and 7 years, respectively, after planting.

The soil in experiment I was infested with the defoliating pathotype of $V$. dahliae. This is the first record of its presence in commercial olive orchards in Spain, where only the mildly pathogenic nondefoliating strain of $V$. dahliae had been described $(8,13)$. The highly virulent pathogenic (cotton-defoliating) isolate has been described in Europe, where it was re- stricted to the Marismas area of Andalucía, southern Spain, where it affects cotton (10). Subsequent reports demonstrated that this strain was spreading to other cottongrowing areas of Spain $(4,7)$. Now, its presence in experiment I, located $150 \mathrm{~km}$ from the Marismas area, shows the ability of the pathogen to spread and represents a serious threat to new olive orchards because of the susceptibility of the commercial olive cultivars grown in Andalucía to this pathotype $(32,41)$.

Soil solarization has been reported as a very effective technique to eradicate soilborne pathogens, in particular $V$. dahliae, and to control Verticillium wilt in several
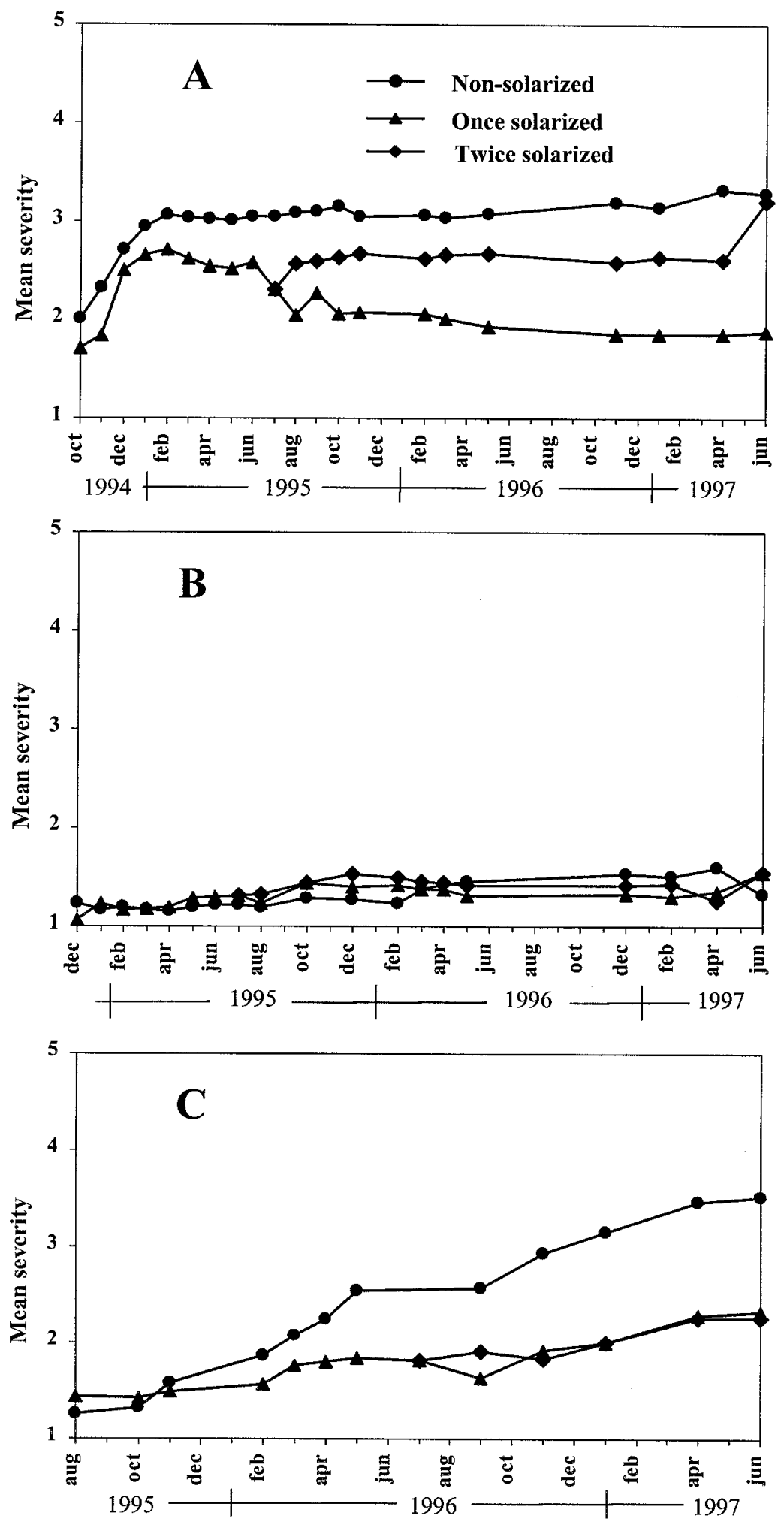

Fig. 2. Effect of soil solarization on disease severity in A, experiment I, B, experiment II, and $\mathbf{C}$, experiment III. 
herbaceous crops $(9,28,38,46)$. Nevertheless, references on woody hosts, specifically olives, are scarce (53). In our experiments, solarization consistently increased soil temperatures related to values reached in control plots. The level of increase varied with field. Continuous recording instruments were not used in 1994 and 1995; therefore, differences of temperature recorded between solarized and nonsolarized controls were probably not the maximum real values (Table 2). However, increases of 6.3 to $12.0^{\circ} \mathrm{C}$ were reached, depending on experiments. These values are similar to those reported by Tjamos (53), ranging from 9 to $12^{\circ} \mathrm{C}$ in soils around individual solarized olive trees in Greece. Nevertheless, the maximum temperatures recorded by Tjamos $(53)$ were higher $\left(48^{\circ} \mathrm{C}\right)$ than in our study $\left(45^{\circ} \mathrm{C}\right)$. In 1996 , temperatures were generally lower than in previous years (maximums of 40.7 and $35.6^{\circ} \mathrm{C}$ at depths of 15 and $30 \mathrm{~cm}$, respectively) but close to the effective range of temperatures necessary to eradicate or reduce populations of $V$. dahliae in soil according to values reported by several authors $(28,37,46)$.

Soil solarization reduced populations of $V$. dahliae in the first $20 \mathrm{~cm}$ of soil with a wide range of inoculum densities: high (experiment I), medium (experiment III), and low (experiment II and IV). In all experiments, solarization caused a long-lasting (3 years) decrease in the inoculum density of $V$. dahliae. Nevertheless, eradication was not complete at any recording period, and certain increments in inoculum density were detected later, even after the second solarization. The residual noncontrolled populations might be responsible for the inoculum build up due to lower temperatures occurring in shaded zones $(2,33,53)$, escape of microsclerotia present in deeper clay layers $(2,53)$, or viable microsclerotia that remained at the borders of solarized plots $(23,39)$. In addition, weeds, especially in experiment III, may allow increase or maintenance of the pathogen in soils as reported by several authors $(25,31,51,58)$.

The low inoculum density of the pathogen observed after the first solarization masked the effect of a second solarization. Some residual populations of $V$. dahliae remained after the second solarization. There are no reports on the effect of two consecutive applications of solarization but important modifications could have occurred in the natural populations of $V$. dahliae and other soil microorganisms. For instance, Tjamos (53) observed an increase in the populations of two antagonists, $\mathrm{Ta}$ laromyces flavus and Aspergillus terreus, after a single solarization treatment in olive.

Despite high disease incidence values, the failure to detect inoculum in experiment III in July 1995 is in agreement with observations in olive (32) and cotton (4) fields that report low to medium incidences of Verticillium wilt with low or nondetected pathogen populations. Other authors have reported low success in detecting the pathogen in soil in certain periods of the year (19). However, a large increase of inoculum density was detected after the summer, in this and the rest of the experimental plots, in relation to the initial values. This increase in the populations of $V$. dahliae during the fall has been reported by Melero-Vara et al. (34) in infested cotton fields. Such increases could, in part, be explained by the release of microsclerotia from infested debris and more favorable temperatures for growth of the pathogen (57). Additionally, in experiment III, drip irrigation might have an influence on the increase of inoculum density. Thus, around wet areas, where the samples were taken, defoliated leaves may have provided an inoculum source. Therefore, an external

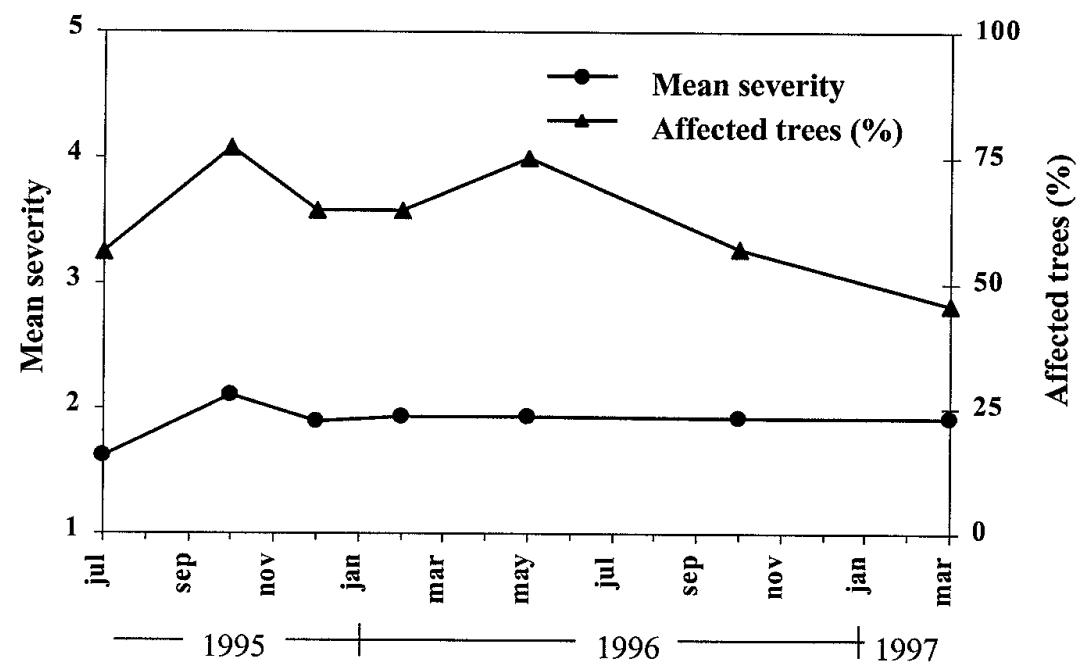

Fig. 3. Effect of individual soil solarization on severity of symptoms and disease incidence in experiment IV. source of infested material might find a continuously wet area to decompose and release microsclerotia of the pathogen $(16,21)$. Finally, weeds growing in wet places during the summer could have maintained and even increased the inoculum of $V$. dahliae (51).

Natural populations of the pathogen showed temporal and spatial variations. Inoculum density in the nonsolarized control plots ranged from 16.4 to $28.6,0.5$ to 3.6, and 0 to $13.3 \mathrm{ppg}$ in experiments I, IIIV, and III, respectively. This fact has been observed in fallow soils (6) and in established olive tree plantations (52) where soil populations of $V$. dahliae varied. Distribution models for $V$. dahliae are scarce and studies carried out by Bejarano-Alcázar and Jiménez-Díaz (5) in cotton-growing areas of southern Spain show that these models do not fit standard distributions.

The higher inoculum density in soils in experiment I was related to the presence of the defoliating pathotype of $V$. dahliae, as reported by Bejarano-Alcázar et al. (4), in the cotton-growing areas at Marismas in the Guadalquivir Valley, where levels of $132 \mathrm{ppg}$ have been found in soil infested with these isolates. The reduction of inoculum by solarization at this site, where mixtures of defoliating and nondefoliating pathotypes were present, is consistent with the results of solarization in cotton fields infested with both pathotypes (34).

The effect of solarization on Verticillium wilt of olive did not follow the same pattern as effects on inoculum density. In experiments I and III, single-solarization treatments reduced the AUDPC, but double-solarization treatments only reduced the AUDPC values to intermediate levels (Table 4). Other disease parameters were not reduced. Therefore, mean severity was reduced by single-solarization treatments in experiments I and III, while doublesolarization treatments only reduced it in experiment III (Table 4, Fig. 2A and C). Disease incidence was reduced only in double solarization treatments in experiment III (Table 4, Fig. 1C).

The effectiveness of soil solarization could depend on the inoculum density and strain of $V$. dahliae and the type of soil. In our experiments with high inoculum density or the defoliating pathotype (as in experiment I), a reduction in severity of infections (mean severity and AUDPC) is satisfactorily reached after the first solarization. The significant reduction of inoculum density by the first solarization (from 11 to $1.1 \mathrm{ppg}$ ) did not bring about a reduction of disease incidence. Presumably, trees were already infected the spring before solarization in 1994, although new infections due to residual microsclerotia present in deeper layers or in shaded parts of the tree cannot be discarded $(2,53)$. However, the reduction of the inoculum density in solarized soil in the summer 1994 decreased the number of subsequent infec- 
tions in the fall and, consequently, could have reduced the severity observed the next spring (from February 1995) as shown by Huisman and Gerik (27) in cotton and tomato roots. On the other hand, available reports in the literature related to control of Verticillium wilt of olive by solarization refer to soils infested with nondefoliating isolates. Therefore, results of experiment I might not be comparable because soil in this field was infested with defoliating isolates of $V$. dahliae.

The reduction from high to low inoculum density and its effect on disease severity is in agreement with Powelson (36), who reported that, when inoculum density in the soil is high, as in experiment I, significant reductions in inoculum would be necessary to reach a significant reduction in disease severity. This implies no recovery of symptoms and an increase in plant mortality in nonsolarized soils (Table 4). On the other hand, incidence of disease in affected trees was only reduced in the sandy loam soil when the soil was infested with a low inoculum density of the nondefoliating pathotype (experiment III).

The effect of the second solarization was also interesting and surprising in some cases. Despite a reduction in the inoculum density related to the nonsolarized control and, in some instances, related to plots once solarized, this effect did not correspond to a reduction in disease. Although a single solarization seems to activate the microbial populations antagonistic to $V$. dahliae $(53,55)$, the double-solarization treatment reduces this population. In general, its effect was intermediate and nonsignificant compared with single-solarization and nonsolarized treatments. Therefore, double soil solarization does not seem warranted.

Soil solarization contributed to an increase in the natural recovery of trees from Verticillium wilt of olive, particularly in experiments I and III, as was demonstrated in the trunk measurements. Results showed that olive trees may overcome wilt over time if an appropriate integrated control strategy is applied, especially where low inoculum density occurs in soils infested with nondefoliating isolates of $V$. dahliae.

\section{ACKNOWLEDGMENTS}

We thank W. J. Kaiser for previous reviewing of the manuscript; E. Pérez-Artes (IAS-CSIC, Córdoba) for PCR technical assistance; and the owners of the olive orchards, F. Borrego, A. Redondo, and F. Parladé, for permitting the authors to conduct experiments on their property.

\section{LITERATURE CITED}

1. Al-Ahmad, M. A., and Mosli, M. N. 1993. Verticillium wilt of olive in Syria. EPPO Bull. 23:521-529.

2. Ashworth, L. J., and Gaona, S. A. 1982. Evaluation of clear polyethylene mulching for controlling Verticillium wilt in established pistachio nut groves. Phytopathology 72:243246.

3. Barranco, D., Fernández-Escobar, R., and Rallo, L., eds. 1997. El Cultivo del Olivo.
Edic. Mundi-Prensa, Madrid.

4. Bejarano-Alcázar, J., Blanco-López, M. A., Melero-Vara, J. M., and Jiménez-Díaz, R. M. 1996. Etiology, importance and distribution of Verticillium wilt of Cotton in southern Spain. Plant Dis. 80:1233-1238.

5. Bejarano-Alcázar, J., and Jiménez-Díaz, R. M. 1997. Analysis of the spatial distribution pattern of Verticillium dahliae in soil of cotton fields. Page 87 in: Proc. 7th Int. Verticillium Symp. Cape Sounion, Athens, Greece.

6. Bejarano-Alcázar, J., Melero-Vara, J. M., Blanco-López, M. A., and Jiménez-Díaz, R. M. 1995. Influence of inoculum density of defoliating and non-defoliating pathotypes of Verticillium dahliae on epidemics of Verticillium wilt of cotton in southern Spain. Phytopathology 85:1474-1481.

7. Blanco-López, M. A., Bejarano-Alcázar J., Melero-Vara J. M., and Jiménez-Díaz R. M. 1989. Current status of Verticillium wilt of cotton in southern Spain. Pathogen variation and population in soil. Pages 123-132 in: Vascular Wilt Diseases of Plants. E. C. Tjamos and C. H. Beckman, eds. NATO ASI Series H: Cell Biology, vol. 28. SpringerVerlag, New York.

8. Blanco-López, M. A., Jiménez-Díaz R. M., and Caballero, J. M. 1984. Symptomatology, incidence and distribution of Verticillium wilt of olive trees in Andalucía. Phytopathol. Mediterr. 23:1-8.

9. Blanco-López, M. A., Jiménez-Díaz, R. M., Melero-Vara J. M., and Bejarano-Alcázar J. 1992. Integrated control of Verticillium wilt of cotton by soil solarization and tolerant cultivars. Pages 63-67 in: Biological Control of Plant Diseases. E. C. Tjamos, G. C. Papavizas, and R. J. Cook, eds. Plenum Press, New York.

10. Blanco-López, M. A., Melero-Vara, J. M., Bejarano-Alcázar, J., and Jiménez-Díaz, R. M. 1986. Distribution and pathogenicity of Verticillium dahliae isolates infecting cotton in Andalucía, southern Spain. In: Proc. 4th Int. Verticillium Symp. Guelph, Ontario, Canada.

11. Blanco-López, M. A., Rodríguez-Jurado, D., and Jiménez-Díaz, R. M. 1990. Incidence and seasonal variation of Verticillium wilt in olive orchards. Page 5 in: Proc. 5th Int. Verticillium Symp. Leningrad, USSR.

12. Butterfield, E. J., and DeVay, J. E. 1977. Reassessment of soil assays for Verticillium dahliae. Phytopathology 67:1073-1078

13. Caballero, J. M., Perez-Hernández, J., BlancoLópez, M. A., and Jiménez-Díaz, R. M. 1980. Olive, a new host of Verticillium dahliae in Spain. Page 50 in: Proc. 5th Congr. Mediterr. Phytopathol. Union, Patras, Greece.

14. Campbell, C. L., and Madden, L. V. 1990. Introduction to Plant Disease Epidemiology. John Wiley and Sons, New York.

15. Cirulli, M., and Montemurro, G. 1976. A comparison of pathogenic isolates of Verticillium dahliae and sources of resistance in olive. Agric. Conspectus Sci. 39:469-476.

16. DeVay, J. E., and Pullman, G. S. 1984. Epidemiology and ecology of diseases caused by Verticillium species, with emphasis on Verticillium wilt of cotton. Phytopathol. Mediterr. 23:95-108.

17. Easton, G. D., Nagle, M. E., and Bailey, D. L. 1969. A method of estimating Verticillium albo-atrum propagules in field soil and irrigation water. Phytopathology 59:1171-1172.

18. Elad, Y., Katan, J., and Chet, I. 1980. Physical, biological and chemical control integrated for soilborne diseases in potatoes. Phytopathology 70:418-422.

19. Evans, G., Snyder, W. C., and Wilhelm, S. 1966. Inoculum increase of the Verticillium wilt fungus in cotton. Phytopathology 56:590594.
20. Freeman, S., Sztejnberg, A., Shabi, E., and Katan, J. 1990. Long-term effect of soil solarization for the control of Rosellinia necatrix in apple. Crop Prot. 9:312-316.

21. Green, R. J., Jr. 1980. Soil factors affecting survival of microsclerotia of Verticillium dahliae. Phytopathology 70: 353-355.

22. Greenberger, A., Yogev, A., and Katan, J. 1987. Induced suppressiveness in solarized soils. Phytopathology 77:1663-1667.

23. Grinstein, A., Kritzman, G., Hetzroni, A., Gamliel, A., Mor, M., and Katan, J. 1995. The border effect of soil solarization. Crop Prot. 14:315-320.

24. Hartman, H., Schnathorst, W. C., and Whysler, J. 1971. Oblonga, a clonal olive rootstock resistant to Verticillium wilt. Calif. Agric. 25(6):13-15.

25. Heale, J. B. 1988. Verticillium spp., the cause of vascular wilt diseases in many species. Pages 291-312 in: Advances in Plant Pathology, vol. 6. D. S. Ingram and P. M. Williams, eds. Academic Press, New York.

26. Huisman, O. C., and Ashworth, L. J. 1974. Quantitative assessment of Verticillium alboatrum in field soils: procedural and substrate improvements. Phytopathology 64:10431044.

27. Huisman, O. C., and Gerik, J. S. 1989. Dynamics of colonization of plant roots by Verticillium dahliae and other fungi. Pages 1-17 in: Vascular Wilt Diseases of Plants. NATO ASI Series H: Cell Biology, vol. 28. E. C. Tjamos and C. H. Beckman, eds. SpringerVerlag, New York.

28. Katan, J. 1980. Solar pasteurization of soil for disease control: status and prospects. Plant Dis. 64:450-454.

29. Katan, J., DeVay, J. E., and Greenberger, A 1989. The biological control induced by soil solarization. Pages 493-499 in: Vascular Wilt Diseases of Plants. NATO ASI Series H: Cell Biology, vol. 28. E. C. Tjamos and C. H Beckman, eds. Springer-Verlag, New York.

30. Katan, J., Fishler, G., and Grinstein, A. 1983. Short- and long-term effects of soil solarization and crop sequence on Fusarium wilt and yield of cotton in Israel. Phytopathology 73:1215-1219.

31. Lacy, M. L., and Horner, C. E. 1966. Behavior of Verticillium dahliae in the rhizosphere and on roots of plants susceptible, resistant, and immune to wilt. Phytopathology 56:427-430.

32. López-Escudero, F. J. 1999. Evaluación de la resistencia de olivo a las variantes patogénicas de Verticillium dahliae y eficacia de la solarización en el control de la verticilosis. Ph.D. Thesis, Univ. Córdoba, Spain.

33. López-Herrera, C. J., Pérez-Jiménez, R. M., Zea-Bonilla, T., Basallote-Ureba, M. J., and Melero-Vara, J. M. 1998. Soil solarization in established avocado trees for control of $D e$ matophora necatrix. Plant Dis. 82:1088-1092.

34. Melero-Vara, J. M., Blanco-López, M. A. Bejarano-Alcázar, J., and Jiménez-Díaz, R. M. 1995. Control of Verticillium wilt of cotton by means of soil solarization and tolerant cultivars in southern Spain. Plant Pathol. 44:250260.

35. Perez-Artés, E., García-Pedrajas, M. Bejarano-Alcázar, J., Korolev, N., RodríguezJurado, D., Katan, T., Katan, J., and JiménezDíaz, R. M. 1997. Comparative RAPD analysis of cotton isolates of Verticillium dahliae from Israel and Spain. Page 14 in: Proc. 7th Int. Verticillium Symp. Cape Sounion, Athens, Greece.

36. Powelson, R. L. 1970. Significance of population level of Verticillium in soil. Pages 3133 in: Root Diseases and Soilborne Pathogens. T. A. Toussoun, R. V. Bega, and P. E. Nelson, eds. Univ. Calif. Press, Berkeley and Los Angeles. 
37. Pullman, G. S., DeVay, J. E., and Garber, R. H. 1981. Soil solarization and thermal death: a logarithmic relationship between time and temperature for four soilborne plant pathogens. Phytopathology 71:959-964.

38. Pullman, G. S., DeVay, J. E., Garber R. H., and Weinhold, A. R. 1979. Control of soilborne fungal pathogens by plastic tarping of soils. Pages: 439-446 in: Soilborne Pathogens. B. Schippers and W. Gams, eds. Academic Press, New York.

39. Pullman, G. S., DeVay, J. E., Garber, R. H., and Weinhold, A. R. 1981. Soil solarization: effects on Verticillium wilt of cotton and soilborne populations of Verticillium dahliae, Pythium spp., Rhizoctonia solani and Thielaviopsis basicola. Phytopathology 71:954959.

40. Rodríguez-Jurado, D. 1993. Interacciones huesped-parasito en la marchitez del olivo (Olea europaea L.) inducida por Verticillium dahliae Kleb. Ph.D. Thesis, Univ. Córdoba, Spain.

41. Rodríguez-Jurado D., Blanco-López, M. A., Rappoport, H. F., and Jiménez-Díaz R. M. 1993. Present status of Verticillium wilt of olive in Andalucía (southern Spain). EPPO Bull. 23:513-516.

42. Saydam, C., and Copcu, M. 1972. Verticillium wilt of olives in Turkey. J. Turk. Phytopathol. 1:45-49.

43. Schnathorst, W. C. 1973. Additional strains of Verticillium dahliae from cotton in California. Pages 22-23 in: Proc. Beltwide Cotton Prod. Res. Conf. Natl. Cotton Counc. Am. Memphis, TN.

44. Schnathorst, W. C., and Sibbet, G. S. 1971. The relations of strains of Verticillium albo- atrum to severity of Verticillium wilt in Gossypium hirsutum and Olea europaea in California. Plant Dis. Rep. 55:780-782.

45. Serrhini, M. N., and Zeroual, A. 1995. La Verticilosis del olivo en Marruecos. Olivae 58:58-61.

46. Stapleton, J. J., and DeVay, J. E. 1986. Soil solarization: a non-chemical approach for management of plant pathogens and pest. Crop Prot. 5:190-8.

47. Stapleton, J. J., Paplomatas, E. J., Wakeman, R. J., and DeVay, J. E. 1993. Establishment of apricot and almond trees using soil mulching with transparent (solarization) and black polyethylene film. Effects on Verticillium wilt and tree health. Plant Pathol. 42:333-338.

48. Sztejnberg, A., Freeman, S., Chet, I., and Katan, J. 1987. Control of Rosellinia necatrix in soil and in apple orchards by solarization and Trichoderma harzianum. Plant Dis. 71:365-369.

49. Thanassoulopoulos, C. C. 1993. Spread of Verticillium wilt by nursery plants in olive groves in the Halkidiki (Greece). EPPO Bull. 23:517-520.

50. Thanassoulopoulos, C. C., Biris, D. A., and Tjamos, E. C., 1979. Survey of Verticillium wilt of olive trees in Greece. Plant Dis. Rep. 63:936-940.

51. Thanassoulopoulos, C. C., Biris, D. A., and Tjamos, E. C. 1981. Weed host as inoculum source of Verticillium in olive orchards. Phytopathol. Mediterr. 20:164-168.

52. Tjamos, E. C. 1983. Prospects for controlling wilt of olive trees by soil solarization. Page 15 in: Hellenic Congr. Plant Dis. Pests, Athens, Hellas, Greece.

53. Tjamos, E. C. 1991. Recovery of olive trees with Verticillium wilt after individual application of soil solarization in established olive orchards. Plant Dis. 75:557-562.

54. Tjamos, E. C., and Fravel, D. R. 1995. Detrimental effects of sublethal heating and $T a$ laromyces flavus on microsclerotia of Verticillium dahliae. Phytopathology 85:388-392.

55. Tjamos, E. C., and Paplomatas, E. J. 1987 Effect of soil solarization on the survival of fungal antagonist of Verticillium dahliae. EPPO Bull. 17:643-653.

56. Tjamos, E. C., and Paplomatas, E. J. 1988. Long-term effect of soil solarization in controlling Verticillium wilt of globe artichokes in Greece. Plant Pathol. 37:507-515.

57. Tjamos, E. C., and Tsougriani, H. 1990. Formation of Verticillium dahliae microsclerotia in partially disintegrated leaves of Verticillium affected olive trees. Page 20 in: Proc. 5th Int. Verticillium Symp. Leningrad, USSR.

58. Vargas-Machuca, R., Martín, C., and Galíndez, W. 1987. Recovery of Verticillium dahliae from weed plants in farmers fields in Peru. Plant Dis. 71:756-758.

59. Vigouroux, A. 1975. Verticillium dahliae, agent d'un déperissement de l'olivier en France. Ann. Phytopathol. 7:37-44.

60. Wilhelm, S., Kaiser, W. J., Georgopoulos, S. G., and Opitz, K. W. 1962. Verticillium wilt of olives in California. (Abstr.) Phytopathology $52: 32$.

61. Wilhelm, S., and Taylor J. B. 1965. Control of Verticillium wilt in olive through natural recovery and resistance. Phytopathology 55:310-316.

62. Zachos, D. G. 1963. La verticilliose de l'olivier en Gréce. Ann. Inst. Phytopathol. Benaki N.S. 5:105-107. 